\title{
Observations on the agonistic behavior of the swimming crab Charybdis longicollis Leene infected by the rhizocephalan barnacle Heterosaccus dollfusi Boschma
}

\author{
Gianna Innocenti, Noa Pinter, and Bella S. Galil
}

\begin{abstract}
The effects of the invasive rhizocephalan parasite Heterosaccus dollfusi on the agonistic behavior of the invasive swimming crab Charybdis longicollis were quantitatively analyzed under standardized conditions. The behavior of uninfected male crabs contained more aggressive elements than that of uninfected females. In encounters between infected males, markedly fewer and less aggressive elements were displayed than in encounters between uninfected males, whereas in encounters between infected females, more aggressive elements were displayed than in encounters between uninfected females. It is suggested that the presence of the parasite reduces belligerence in male crabs, possibly to avoid injury and to enhance the life expectancy of host and parasite.
\end{abstract}

Résumé : Les effets d'Heterosaccus dollfusi, un parasite rhizocéphale envahissant, sur le comportement agonistique du crabe nageur envahissant Charybdis longicollis ont été soumis à une analyse quantitative dans des conditions contrôlées. Les crabes mâles sains montrent plus d'éléments d'un comportement agressif que les femelles saines. Les rencontres entre mâles infectés comptent moins d'éléments de comportement agressif et l'agressivité y est moins intense qu'au cours de rencontres entre des mâles sains. Les femelles infectées montrent plus d'éléments de comportement agressif les unes envers les autres que les femelles saines entre elles. Il apparaît donc que la présence du parasite rend les crabes mâles moins belligérants, peut-être pour éviter les blessures et pour améliorer l'espérance de vie des parasites et de leurs hôtes.

[Traduit par la Rédaction]

\section{Introduction}

Previous studies on the behavior of rhizocephalan-infected crabs (Rasmussen 1959; Bishop and Cannon 1979; Ritchie and Høeg 1981; Overstreet 1983; Takahashi et al. 1997) contain but few references to agonistic behavior. Bishop and Cannon (1979) observed that crabs (Portunus pelagicus) parasitized by Sacculina granifera initiated and dominated fewer encounters than nonparasitized crabs comparable in size and of the same sex, whereas Wardle and Tirpak (1991) remarked that crabs (Callinectes sapidus) bearing externae of Loxothylacus

Received 6 June 2002. Accepted 21 November 2002.

Published on the NRC Research Press Web site at http://cjz.nrc.ca on 21 February 2003.

G. Innocenti. ${ }^{1}$ Museo di Storia Naturale dell'Università di Firenze, Sezione Zoologica 'La Specola', via Romana 17, 50125 Firenze, Italy.

N. Pinter. Department of Zoology, Tel Aviv University, Tel Aviv, 69978, Israel.

B.S. Galil. Israel Oceanographic and Limnological Research, National Institute of Oceanography, P.O. Box 8030, Haifa 31080, Israel.

${ }^{1}$ Corresponding author (e-mail: ganesh@unifi.it). texanus were "generally less active and consistently less aggressive when presented with food".

The erythrean portunid crab Charybdis longicollis Leene invaded the Mediterranean Sea half a century ago (Holthuis 1961; Lewinsohn and Holthuis 1964). Off the Israeli coast, C. longicollis is commonly found on sandy-mud bottoms at 25-60 m depth, forming as much as 70\% of the benthic biomass in places (Galil and Lewinsohn 1981; Galil 1986; Galil and Lützen 1995). Since 1992, the crab's Levantine populations have been infected by the erythrean rhizocephalan Heterosaccus dollfusi Boschma (Galil and Lützen 1995; Galil and Innocenti 1999). The behavior of the infected crabs at different stages of parasitism was examined and compared with the behavior of uninfected crabs. Locomotion, rest, grooming of the body, eggs, and externa, digging and burying themselves, courtship, and mating were described qualitatively and analyzed quantitatively under standardized conditions (Innocenti et al. 1998).

The present work is part of a research effort to study the impact of the invasive rhizocephalan parasite $H$. dollfusi on populations of the invasive swimming crab C. longicollis in the Levantine Sea. A previous study (Innocenti et al. 1998) had already revealed significant modifications in the infected crabs' behavior. This note presents the effects of the parasite on the agonistic behavior of the host crab, quantitatively 
analyzed under standardized conditions, to determine whether aggressiveness is affected by the parasite as well.

\section{Material and methods}

Infected and uninfected $C$. longicollis were obtained from coastal trawl fishery bycatch in Haifa Bay, Israel, at depths of 15-20 $\mathrm{m}$ in November 1995; the overall rate of infestation with $H$. dollfusi was $77 \%$. The crabs were transferred to the National Institute of Oceanography, Haifa, and kept in seawater aquaria $(100 \times 50 \times 50 \mathrm{~cm})$ partitioned into cells. The crabs were fed sliced squid twice a week; the seawater in the aquaria was changed after each feeding. Rhizocephalan infestation was determined from the shape of the abdomen, the lack of pleopods, the position of the gonopores, and the presence of externae. Infected and uninfected individuals were kept in separate aquaria. The crabs' carapace length (CL) was measured along the median line. The 256 crabs $(C L=13.5-$ $32.7 \mathrm{~mm})$ were subdivided into uninfected males $(\mathrm{M})(n=$ $64)$, infected males (MI) $(n=77)$, uninfected females $(\mathrm{F})$ $(n=58)$, and infected females (FI) $(n=57)$. Infected crabs were individuals with an internal infection, a virgin externa, a mature externa, or a scar indicating the previous presence of an externa.

To avoid a size bias, which had been noted in the course of the previous observations, crabs of comparable sizes were chosen for each set of observations. The size difference never exceeded $3.5 \%$ of the average size of the pair. To increase motivation to engage in agonistic behavior, each crab was isolated in a 5-L bucket and denied food for 2-3 days before each experiment. The two members of each size-matched pair were released at opposite ends of a white pan (diameter $29 \mathrm{~cm}$ ) and their behavior was monitored and recorded for a 10-min acclimation period, after which a slice of squid was placed in the middle of the pan. Monitoring continued until the food was consumed, or, if it was consumed sluggishly, up to $10 \mathrm{~min}$ from the time it was placed in the pan. The pan was rinsed clean between encounters.

In accordance with the behavioral elements identified by Bergamo et al. (1988), the crabs' behavior was assigned to the following behavioral elements: approach (AP), i.e., moving towards the opponent; alarm and stay (ALST), i.e., staying motionless with the body raised on the first and second pereiopods, with the open-clawed chelipeds extended laterally; alarm and approach (ALAP), i.e., approaching an opponent while raised on the first and second pereiopods, with the chelipeds extended laterally; contact with the opponent (CO), i.e., using the chelipeds; this behavior included using the chelipeds to either touch or grasp the opponent; food grab (FG), i.e., grabbing food from the center of the pan; food grab from the opponent (FGO), i.e., grabbing food held by the opponent. Withdrawal and remaining motionless were considered nonaggressive responses and were excluded from the results.

We examined encounters between crabs with comparable parasite loads and of the same sex (M vs. M $(n=12), \mathrm{F}$ vs. F $(n=9)$, MI vs. MI $(n=16)$, FI vs. FI $(n=8))$ and between crabs of disparate parasite loads and opposite sexes (M vs. F $(n=14)$, MI vs. FI $(n=17), \mathrm{M}$ vs. MI $(n=14), \mathrm{F}$ vs. FI $(n=$ $12), \mathrm{M}$ vs. FI $(n=12), \mathrm{F}$ vs. MI $(n=14))$, for a total of 128 pairs. At the conclusion of the study the crabs were released into the sea.

The frequencies of each of the elements of the behavior patterns enacted by each of the four categories of crabs (M, F, MI, FI) were compared using a $G$ test (with Williams' correction for $n<50$; Sokal and Rohlf 1981). To analyze the intensity of the behavior, the behavioral elements were scored: AP, the least aggressive element, was given a value of 1 , ALAP and ALST a value of 2, and CO, FG, and FGO a value of 3 . Agonism between crab pairs with comparable parasite loads and of the same sex was compared by applying the Mann-Whitney test to those scores (Siegel 1956).

\section{Results}

The presence of food did not significantly alter the crabs' behavior in any of the tests, therefore the results of the two treatments were pooled.

\section{Encounters between crabs with comparable parasite loads and of the same sex}

The male crabs performed more behavioral elements than the females, the latter tending to remain motionless. The least aggressive behavioral patterns (AP, ALST, ALAP) were the most commonly observed in all encounters. The behavior patterns of uninfected males differed significantly from those of uninfected females, whereas the behavior patterns of infected males and females were comparable (Table 1A).

Uninfected male crabs (M vs. M) tended to stay motionless with extended chelipeds (ALST) or to contact their opponent $(\mathrm{CO})$, whereas most uninfected females ( $\mathrm{F}$ vs. F) favored the least aggressive element (AP), and few contacted their opponent. However, whereas infected males (MI vs. $\mathrm{MI})$ tended to engage their opponent (CO) less than uninfected males did, infected females (FI vs. FI) displayed an increase in both aggressive elements (ALST and CO). Comparisons between categories for patterns such as AP, ALAP, FG, and FGO did not show any differences, while the differences for the ALST and CO patterns are summarized in Table 2. The $\mathrm{CO}$ pattern seems to be the one that distinguished the behavior of uninfected males, with the exception of the comparison between $\mathrm{MI}$ and FI, where $\mathrm{CO}$ was slightly more significant in FI (Table 2).

FG was displayed nearly equally by male and female crabs, both infected and uninfected, while FGO hardly ever occurred in pairs of two males, or in pairs consisting of infected and uninfected males and females.

The intensity of aggressive behavior exhibited by each category of crabs is compared in Table 3, confirming the above results.

\section{Encounters between crabs of disparate parasite loads and of the opposite sex}

For each encounter, the percentages of behavior-pattern frequency are presented in Table 1B. A comparison of frequencies showed that ALST and $\mathrm{CO}$ were significant in $\mathrm{M}$ vs. F encounters, where males were more prone to exhibit such a pattern (M vs. F: ALST pattern, $G=18.81$, df $=1$, $P<0.001$; CO pattern, $G=5.487$, df $=1, P<0.02$ ). In MI vs. FI and M vs. MI encounters, the uninfected males and infected females showed a slight tendency to contact the op- 
Table 1. Observed frequency (\%) of elements in the behavior of the crab Charybdis longicollis.

(A) Encounters between crabs with comparable parasite loads and of the same sex (M vs. M ( $n=12)$; F vs. F ( $n=9)$; MI vs. MI $(n=16)$; FI vs. FI $(n=8))$.

\begin{tabular}{lrrrr}
\hline & \multicolumn{1}{c}{ M } & \multicolumn{1}{c}{ F } & \multicolumn{1}{c}{ MI } & \multicolumn{1}{c}{ FI } \\
\hline AP & 18.9 & 58.0 & 35.6 & 31.1 \\
ALST & 40.6 & 4.0 & 27.4 & 27.8 \\
ALAP & 15.0 & 22.0 & 25.3 & 20.0 \\
CO & 20.0 & 7.0 & 4.1 & 12.2 \\
FG & 5.6 & 8.0 & 7.5 & 7.8 \\
FGO & 0.0 & 1.0 & 0.0 & 1.1 \\
Total & 100 & 100 & 100 & 100
\end{tabular}

(B) Encounters between crabs with disparate parasite loads and of the opposite sex.

\begin{tabular}{|c|c|c|c|c|c|c|c|c|c|c|c|c|}
\hline & \multicolumn{2}{|c|}{$\mathrm{M}$ vs. $\mathrm{F}(n=14)$} & \multicolumn{2}{|c|}{ MI vs. FI $(n=17)$} & \multicolumn{2}{|c|}{ M vs. MI $(n=14)$} & \multicolumn{2}{|c|}{ F vs. FI $(n=12)$} & \multicolumn{2}{|c|}{$\mathrm{M}$ vs. FI $(n=12)$} & \multicolumn{2}{|c|}{ F vs. MI $(n=14)$} \\
\hline & M & $\mathrm{F}$ & MI & FI & $\mathrm{M}$ & MI & $\mathrm{F}$ & FI & $\mathrm{M}$ & FI & $\mathrm{F}$ & MI \\
\hline$\overline{\mathrm{AP}}$ & 13.3 & 35.5 & 30.1 & 44.8 & 24.3 & 34.3 & 40.9 & 48.9 & 32.7 & 36.4 & 32.1 & 43.8 \\
\hline ALST & 20.0 & 30.6 & 22.6 & 25.0 & 28.4 & 21.4 & 36.4 & 33.3 & 23.1 & 27.3 & 26.4 & 25.0 \\
\hline $\mathrm{CO}$ & 17.3 & 6.5 & 15.1 & 7.3 & 23.0 & 4.3 & 6.8 & 6.7 & 7.7 & 9.1 & 9.4 & 12.5 \\
\hline FG & 13.3 & 9.7 & 12.9 & 4.2 & 5.4 & 8.6 & 11.4 & 6.7 & 13.5 & 6.1 & 3.8 & 4.7 \\
\hline
\end{tabular}

Note: Categories of crabs are as follows: M, uninfected males, F: uninfected females, MI: infected males, FI: infected females. Elements of behavior patterns are designated as follows: AP, approach; ALST, alarm and stay; ALAP, approach the opponent; CO, contact with the opponent; FG, food grab; FGO, food grab from the opponent.

Table 2. Comparison of significant behavioral elements observed in encounters between pairs of uninfected and infected crabs.

\begin{tabular}{|c|c|c|c|c|}
\hline & M & $\mathrm{F}$ & MI & FI \\
\hline \multicolumn{5}{|l|}{ ALST } \\
\hline \multicolumn{5}{|l|}{$\mathrm{M}$} \\
\hline $\mathrm{F}$ & $G=18.812, \mathrm{df}=1, P<0.001$ & & & \\
\hline MI & $G=7.753, \mathrm{df}=1, P<0.01$ & $G=4.565, \mathrm{df}=1, P<0.05$ & & \\
\hline FI & $G=4.703, \mathrm{df}=1, P<0.05$ & $G=4.041, \mathrm{df}=1, P<0.05$ & ns & \\
\hline \multicolumn{5}{|l|}{$\mathrm{CO}$} \\
\hline \multicolumn{5}{|l|}{ M } \\
\hline $\mathrm{F}$ & $G=5.487, \mathrm{df}=1, P<0.02$ & & & \\
\hline MI & $G=13.181, \mathrm{df}=1, P<0.001$ & ns & & \\
\hline FI & ns & ns & $\mathrm{G}=3.621, \mathrm{df}=1, P<0.5$ & \\
\hline
\end{tabular}

Note: Frequencies were compared using the $G$ test (with Williams' correction for $n<50$ ). For an explanation of abbreviations see Table 1.

ponent, but the infected male crabs did not (MI vs. FI: CO pattern, $G=3.621$, df $=1, P<0.5$; M vs. MI: CO pattern, $G=2.898$, df $=1, P<0.5)$.

FG was displayed by male and female crabs, both infected and uninfected, save for encounters between uninfected males and infected females ( $\mathrm{M}$ vs. FI), where the males did grab the food on most occasions (M vs. FI: FG pattern, $G=$ $4.345, \mathrm{df}=1, P<0.05)$. The FGO pattern seldom occurred in couples of infected and uninfected males and females.

\section{Discussion}

The presence of $H$. dollfusi greatly modifies the morphology of its host, C. longicollis (Galil and Lützen 1995). Not only does the parasite cause "feminization" of the secondary sex characters, but infected male hosts are undersized com- pared with uninfected ones, an indication of feminization, whereas infected female hosts are larger than uninfected ones (Galil and Innocenti 1999). The presence of the externae of $H$. dollfusi alters the behavior patterns of $C$. longicollis: hosts, both male and female, spend much of their time cleaning and tending the externae in imitation of egg-grooming behavior, and are barely able to bury themselves in the sediment (Innocenti et al. 1998).

Patterns of intraspecific agonistic interactions have been studied in several brachyuran crabs, mostly intertidal and semiterrestrial species (Griffin 1965; Schöne 1968; Hazlett 1972; Hazlett and Estabrook 1974; Jachowski 1974; Evans et al. 1976; Jacoby 1981), and they suggest that males perform more elements of agonistic behavior patterns, such as contact, than females. However, Bishop and Cannon (1979), who studied agonistic interactions between opposite- and 
Table 3. Comparison of the intensity of aggressive behavior among categories of crabs.

\begin{tabular}{|c|c|c|c|c|c|c|}
\hline & $\begin{array}{l}\text { Uninfected } \\
\text { crabs }\end{array}$ & $\begin{array}{l}\text { Infected } \\
\text { crabs }\end{array}$ & & & & \\
\hline M & 15.5 & 8.0 & & & & \\
\hline$\underline{F}$ & 8.8 & 10.7 & & & & \\
\hline \multicolumn{7}{|c|}{ (B) Comparison between categories of crabs (Mann-Whitney test). } \\
\hline & \multicolumn{2}{|l|}{ M } & \multicolumn{2}{|l|}{$\mathrm{F}$} & \multicolumn{2}{|l|}{ MI } \\
\hline & $U$ & $P$ & $U$ & $P$ & $U$ & $P$ \\
\hline $\mathrm{F}$ & 131.5 & 0.0162 & - & - & - & - \\
\hline MI & 230 & 0.0055 & 286 & ns & - & - \\
\hline FI & 137 & 0.0655 & 140 & $\mathrm{~ns}$ & 227 & ns \\
\hline
\end{tabular}

same-sex pairs of crabs ( $P$. pelagicus) uninfected and infected with $S$. granifera, reported that infected crabs initiated fewer encounters than uninfected crabs of comparable size and the same sex.

Our study has shown that the behavior patterns enacted by C. longicollis consisted of ritualized low- to medium-intensity agonistic elements, but that the behavior patterns enacted by uninfected male crabs contained more aggressive elements than those of uninfected females. Encounters between infected males were markedly less agonistic than encounters between uninfected males. The feminized agonistic behavior of male crabs parallels the feminization of the secondary sex characters and size range of $H$. dollfusi-parasitized $C$. longicollis. It is also suggested that the presence of the parasite reduces belligerence in male crabs, enhancing injury avoidance and possibly increasing the life expectancy of host and parasite.

\section{Acknowledgement}

We thank M. Vannini, University of Florence, Italy, for his valuable suggestions on an earlier version of the manuscript.

\section{References}

Bergamo, P., Fiorito, G., and Miralto, A. 1988. An analysis of the agonistic behaviour of Carcinus mediterraneus (Czerniavsky) (Crustacea Decapoda): fighting and ritualization. Monit. Zool. Ital. (N.S.), 22: 315-322.

Bishop, R.K., and Cannon, L.R.G. 1979. Morbid behaviour of the commercial sand crab, Portunus pelagicus (L.), parasitized by Sacculina granifera Boschma 1973 (Cirripedia: Rhizocephala). J. Fish Dis. 2: 131-144.

Evans, S.M., Cram, A., Eaton, K., Torrance, R., and Wood, V. 1976. Foraging and agonistic behaviour in the ghost crab Ocypode kuhlii de Haan. Mar. Behav. Physiol. 4: 121-135.

Galil, B.S., and Innocenti, G. 1999. Notes on the population structure of the portunid crab Charybdis longicollis Leene, parasit- ized by the rhizocephalan Heterosaccus dollfusi Boschma, off the Mediterranean coast of Israel. Bull. Mar. Sci. 64: 451-463.

Galil, B.S., and Lewinsohn, C. 1981. Macrobenthic communities of the Eastern Mediterranean continental shelf. Mar. Ecol. 2: 343-352.

Galil, B.S., and Lützen, J. 1995. Biological observations on Heterosaccus dollfusi Boschma (Cirripedia: Rhizocephala), a parasite of Charybdis longicollis Leene (Decapoda: Brachyura), a lessepsian migrant to the Mediterranean. J. Crustacean Biol. 15: $659-670$.

Griffin, D.J.G. 1965. The behaviour of shore crabs. Aust. J. Nat. Hist. 15: 87-91.

Hazlett, B.A. 1972. Stereotypy of agonistic movements in the spider crab Microphrys bicornutus. Behaviour, 42: 270-278.

Hazlett, B.A., and Estabrook, G. 1974. Examination of agonistic behaviour by character analysis. I. The spider crab Microphrys bicornutus. Behaviour, 48: 131-144

Holthuis, L. 1961. Report on a collection of Crustacea Decapoda and Stomatopoda from Turkey and the Balkans. Zool. Verh. 47: $1-67$.

Innocenti, G., Vannini, M., and Galil, B.S. 1998. Notes on the behaviour of the portunid crab Charybdis longicollis Leene parasitized by the rhizocephalan Heterosaccus dollfusi Boschma. J. Nat. Hist. 32: 1577-1585.

Jachowsky, R.L. 1974. Agonistic behaviour of the blue crab, Callinectes sapidus Rathbun. Behaviour, 5: 232-253.

Jacoby, C.A. 1981. Behavior of the purple shore crab Hemigrapsus nudus Dana, 1851. J. Crustacean Biol. 1: 531-544.

Lewinsohn, C., and Holthuis, L.B. 1964. New records of decapod Crustacea from the Mediterranean coast of Israel and the eastern Mediterranean. Zool. Meded. 40: 45-63.

Overstreet, R.M. 1983. Metazoan symbionts of crustaceans. In The Biology of Crustacea. Vol. 6. Pathobiology. Edited by A.J. Provenzano, Jr. Academic Press, New York. pp. 155-250.

Rasmussen, E. 1959. Behaviour of sacculinized shore crabs (Carcinus maenas Pennant). Nature (Lond.), 183: 479-480.

Ritchie, L.E., and Høeg J.T. 1981. The life history of Lernaeodiscus porcellanae (Crustacea, Rhizocephala) and co-evolution with its porcellanid host. J. Crustacean Biol. 1: 334-347.

Schöne, H. 1968. Agonistic and sexual display in aquatic and semiterrestrial brachyuran crabs. Am. Zool. 8: 641-654.

Siegel, S. 1956. Nonparametric statistics for the behavioral sciences. McGraw-Hill Book Co., New York.

Sokal, R.R., and Rohlf, F.J. 1981. Biometry: the principles and practice of statistics in biological research. 2nd ed. W.H. Freeman and Co., San Francisco.

Takahashi, T., Iwashige, A., and Matsuura, S. 1997. Behavioural manipulation of the shore crab, Hemigrapsus sanguineus by the rhizocephalan barnacle, Sacculina polygenea. Crustacean Res. 26: $153-161$.

Wardle, W.J., and Tirpak, A.J. 1991. Occurrence and distribution of an outbreak of infection of Loxothylacus texanus (Rhizocephala) in blue crabs in Galveston Bay, Texas, with special reference to size and coloration of the parasite's external reproductive structures. J. Crustacean Biol. 11: 553-560. 